\title{
The Market Competition, Law Enforcement, and Banking System's Efficiency in China
}

\author{
Yu XIA \\ Department of Law, School of Politics \& Law and Public \\ Administration, Hubei University, Wuhan, China
}

\author{
Xianliang Tian \\ Department of Finance, School of Business, Hubei University, \\ Wuhan, China
}

\begin{abstract}
In economic literature, the benefit of competition is well recognized, for example, it could reduce monopoly rents and cost inefficiencies, and finally improve the welfare of the economy. In the case of banking system, the market competition in banking sector could improve efficiency of the banking system as a whole, and promote economic growth as a result. However, the effect of competition on banking system's efficiency hinges on some environmental factors, such as the efficiency of law enforcement. In this paper, we measure the level and evolution of bank system's competition between 1996 and 2009. Making use of the micro data of Chinese commercial banks from 1996 to 2009, we choose the RP method to measure the competition level of China's banking system. Then we study the relationship between market competition, law enforcement and Chinese banking system efficiency, which shows that higher market completion could lead to more efficient banking system, and this effect is more salient when law enforcement is more efficient.
\end{abstract}

Keywords-Market Competition; Law Enforcement; Banking System; China

\section{Introduction}

In the literature of economic development, the bank system exerts an important role on the economic growth through financial accumulation and fund allocation. While the competition in bank system could reduce the prices of financial services, thus accelerate investment and growth, it also has non-ignorable impacts upon economic development. Besides, a heightened competition should encourage banks to reduce their costs, namely, their cost inefficiencies, which have been shown around 30 to $50 \%$ of the banking sectors' cost in European transitional countries (Hasan and Marton 2001). On the other hand, however, Allen and Gale (2004) indicated that excessive banking competition could encourage excessive risk-taking of banks, hamper the stability of financial system and thus could be seen as a deterrent of economic growth. Therefore, the conclusion about the banking competition's effects is by now not clear-cut.

As to transitional countries like China, the issues about banking competition are especially important, for the bank loan constitutes by far the largest source of funds for companies, and the reduction of cost inefficiencies would lower the loan rate and thus promote investment and economic growth.

The theoretical literature about the link between competition and efficiency is rather rare. Hicks (1935) considers monopoly power as big hindrance to enhance the efficiency of management. In his eyes, monopoly power allows managers to grab a share of the monopoly rents through discretionary expenses or a reduction of their effort. So goes a famous sentence from Hicks: "The best of all monopoly profits is quiet life." However, Hicks had not explained clearly the reason why the managers in monopolistic company would exert less management effort than those in competitive situation. Then Leibenstein (1966) and Demsetz (1973) put forward complementary theories to extend the work of Hicks.

Leibenstein (1966) clarifies the underlying logics between the efficiency and the level of competition of a company using the concept of X-inefficiency. In his theory, the X-inefficiency is the result of imperfection of the organization of the firm, i.e. the information asymmetry between the workers and the owner. Because the production function of the workers is unknown to the owner of the firm, and still some uncontrolled factors could influence the level of production of the workers, the owner of the firm could not figure out if the reduction of production is due to external stochastic factors or the shrinking of the workers. Of course, this kind of information asymmetry might be greatly reduced through thorough and careful supervision of the owner, but the cost of absolute supervision is prohibitively high, and might exceed the potential revenue increase brought about by enhanced effort and production of workers. Then the workers take opportunity of the owner, and shrink, thus make the efficiency of the firm less than it should be, which is called $\mathrm{X}$-inefficiency. However, the competition of production market could reduce X-inefficiency in two ways: first, the workers face the cost of bankruptcy of the firm. The fear of losing their job might force the workers to work hard and thus improve the overall efficiency of the firm. Second, the existence of other familiar firms in the market makes the owner much easier to assess the real production function of the firm and the workers' behavior of shrinking much easier to detect. Following Leibenstein's works, a few studies have proposed a formalization of his ideas (Hart, 1983; Selten, 1986; Scharfstein, 1988). In fact, the X-inefficiency theory from Leibenstein lies within the scope of the "Structure-ConductPerformance” (SCP) paradigm proposed by Bain (1951). According to this paradigm, the market structure would influence firm behavior in terms of prices and quantities, and therefore firm profits.

Demsets (1973) proposes an alternative assumption, i.e. the "efficiency-structure" hypothesis. He sees the efficiency as a determinant of the level of competition: The most efficient firms usually have lowest cost and greatest advantage in 
market competition, thus greatest market share. Still greater market share could facilitate the firm to extract the benefit of scale economy and further lower its cost, thus grab the market share to a larger extent. If concentration could be seen as an inverse function of competition, then the efficiency-structure hypothesis implies the negative correlation between the competition and efficiency.

As to banking industry, the story might be a little different from above, which is referred to general production markets. Generally speaking, the banking industry has an imperfection competition market structure, which is derived from the information asymmetry between the bank and the borrower in credit activity. To relieve the moral hazard and adverse selection problem caused by information asymmetry, the bank tends to form a long-term bank-borrower relationship. However, the competition in banking industry could reduce the term of bank-borrower relationship, thus has a negative impact on the efficiency of banks. So the specific characteristics of banking industry would theoretically hint negative relationship between the competition and efficiency.

The effect of competition on banking system's efficiency also hinges on some environmental factors, such as the efficiency of law enforcement. In theory, the effect will be more salient when the law enforcement in the market is more efficient.

By now only a few empirical studies about the relationship between competition and efficiency in banking industry emerge, for example, Berger (1995), Berger and Hannan (1997), Lang (1996). These papers tend to support a positive relationship between cost efficiency and market share, thus confirm the efficiency-structure hypothesis.

In conclusion, the theoretical outcomes about the relationship between the competition and efficiency are conflicting, while the empirical evidence is in large part in favor of negative relationship between them. So it's rather necessary to provide new evidence about competitionefficiency relationship in banking industry.

\section{The Methodology}

\section{A Measurement of Competition}

In empirical literature, the measurement of banking competition could be divided into two categories: traditional Industrial Organization approach and new empirical Industrial Organization approach. The traditional IO approach assesses banking competition on the basis of SCP model, and the method it proposed is structural tests. In this regard, the competition could be measured by market share of the three biggest banks, or the Herfindahl index. However, the competition level calculated using traditional IO method has obvious shortcomings, i.e. it derives the competition indirectly of some proxies, such as market structure or market shares.

In comparison of traditional IO method, the new IO approach could solve the problems mentioned above. The method of calculating the competition level in new empirical IO approach is non-structural tests. One of the most common used models in new empirical IO approach is Rosse-Panzar model, which is based on the estimation of H-statistics. The Hstatistics is obtained when aggregating the elasticity of total revenues to input prices.

The RP model is based on following assumptions: (1) the banks are operating under long-term equilibrium; (2) the banks are similar and have Cobb-Douglas production function; (3) the conducts of banks are interdependent.

The condition for banks' profit maximization is as below:

$$
\mathrm{R}_{i}^{\prime}\left(x_{i}, n, z_{i}\right)-C_{i}^{\prime}\left(x_{i}, p_{i}, t_{i}\right)=0
$$

In equation (1), $R_{i}^{\prime}$ is the marginal revenue of bank $i, C_{i}^{\prime}$ is the marginal cost of bank $i, x_{i}$ is the output of bank $i$. $n$ is the number of banks, and $p_{i}$ is the price of input of bank $i$. $Z_{i}$ and $t_{i}$ are exogenous independent variable, which could have impact on the revenue function and cost function of banks.

At equilibrium, the condition for zero profit is as follows:

$$
R_{i}^{*}\left(x^{*}, n^{*}, z\right)-C_{i}^{*}\left(x^{*}, p, t\right)=0
$$

In the equation (2), the variables with star mean value in equilibrium.

Then the competition level $\mathrm{H}$ could be calculated as follows:

$$
H=\sum_{k=1}^{m} \frac{\partial R_{i}^{*}}{\partial p_{k i}} \cdot \frac{p_{k i}}{R_{i}^{*}}
$$

In empirical studies, the calculation of $\mathrm{H}$ involves the model as below:

$$
L n R A_{i t}=\alpha_{0}+\alpha_{1} \operatorname{Lnp}_{1, i t}+\alpha_{2} \operatorname{Lnp}_{2, i t}+\alpha_{3} \operatorname{Lnp}_{3, i t}+\varepsilon_{i t}
$$

In equation (4), $R A$ stands for the bank's total income divided by its total asset, $p_{1}$ is calculated by operation cost divided by total asset; $p_{2}$ is interest expenditure divided by total deposits; and $p_{3}$ is the depreciation value of fixed asset divided by its net value. Then, $H$ could be calculated as follows:

$$
H=\alpha_{1}+\alpha_{2}+\alpha_{3}
$$

If $H<0$, then the market is a monopolistic one; if $H=1$, the market is competitive; and if $0<H<1$, then the market is competitive monopolistic. The bigger the value of $H$, the higher the level of competition is.

\section{B Measurement of Efficiency}

There exist two kinds of concepts of technical microefficiency in current literature: cost efficiency and profit efficiency. In this paper, we choose the concept of cost efficiency to measure technical efficiency of individual bank for the facts that a bank's ability to make profits may not coincide with its ability to screen best borrowers. In some cases, 
banks can even get admirable profits through the manipulation of prices, which is especially applicable in Chinese banking sector for its less competitive market structure.

The techniques applied when estimating and entity's technical efficiency usually involve DEA technique, also known as non-parametric techniques and stochastic frontier technique, one of the techniques of parametric estimation. We prefer a parametric technique here to make best of its advantage of allowing one to conduct hypothesis test; besides, the estimation of micro-efficiency with this method is unbiased. In what follows, we will choose stochastic frontier technique to estimate technical efficiency of individual banks.

Berger (1993) gives the general formula for cost efficiency estimation under parametric techniques:

$$
R C=C(Q, W) . U
$$

Here, $R C$ represents real cost, $C(Q, W)$ is theoretically minimal cost. $U \in[1, \infty)$ reflects the degree of cost squander of commercial banks, reciprocal of which denotes the value of cost efficiency. $Q=\left(Q_{1}, Q_{2}, \ldots\right)$ is a vector of quantities for various outputs. And $W=\left(W_{1}, W_{2}, \ldots\right)$ is a vector for prices of inputs.

Taking the logarithm of equation (4), yields:

$$
r C=c(Q, W)+\varepsilon+\mu
$$

In the equation above, $\varepsilon$ is a term of random error; and other variables in lowercase are logarithmic form of the corresponding variables in equation (7).

We should define the inputs and outputs definitely as regard to equation (7) in precedence of conducting regression estimation. In equation (7), price vector takes average cost of loanable funds and average prices of operation inputs as its components. As to average cost of loanable funds, it is defined as the ratio between the sum of commission charged and interest expenditure on bank's liability and average quantity of loanable funds, while the average price of operation inputs is taken as the ratio of operation expenses and average total assets. We take the ratio of operating expenses as a proportion of average total assets as the average price of operation inputs. And bank's outputs are defined as total loans, amount of investment and non-interest proceeds. Finally, for availability of data, we just include three typical items as constituents of total real cost of a bank, which are commission fee charged, interest expenditure and operation expenses respectively.

\section{Samples and Data}

Due to the difficulty of data collection, the sample herein just consists of 4 greatest state-owned banks, there of which have recently been converted to conventional commercial banks through the introducing of new non-government investors, and 10 middle-sized commercial banks; these 14 banks constitute the most part of Chinese banking sector, whose assets amount to nearly $75 \%$ of total assets of this sector as a whole. Taking account of data availability, small size or other reasons, we exclude policy banks, city commercial banks, urban and rural cooperative credit banks and branches of foreign banks in China out of the sample. The time horizon is from 1996 to 2009, which is the critical period for commercial banks' reform in China and with it we can look into the change of micro-efficiency of banks through the reform. The data is mainly extracted from "Year Book of Chinese Finance" and official information published in each bank's website, from which financial data of Guangdong Development Bank in 2009 is still unavailable; we then create a sample of this bank for 2009 by adjusting the data of 2008 adding the average alteration from 2006 to 2008 to each component. Table 1 below gives statistic description of the sample.

\begin{tabular}{|c|c|c|c|}
\hline variable & notion & Mean Value & Standard Error \\
\hline $\mathrm{RC}$ & Real total cost & 300.17 & 165.37 \\
\hline Q1 & Balance of loan & 5738.33 & 8220.21 \\
\hline Q2 & Balance of investment & 2390.54 & 4001.36 \\
\hline Q3 & Non-interest proceeds & 72.32 & 79.65 \\
\hline W1 & $\begin{array}{c}\text { Average cost of loanable } \\
\text { funds }\end{array}$ & 0.0201 & 0.01 \\
\hline W2 & $\begin{array}{l}\text { Average price of operation } \\
\text { inputs }\end{array}$ & 0.019 & 0.009 \\
\hline
\end{tabular}

Table 1: Statistic Description of the Sample

Source: "Year Book of Chinese Finance” (1999-2005) and official statistic data published in every bank's website.

Note: Q1 is the mean value of balance of loan in the observational year (deducted by non-performing loans). Q2 is the mean value of balance of investment, here including shortterm investment, security investment, and long-term investment, deducted by reserve for loss of investment. Q3 is calculated as yearly earning deducted by interest proceeds. W1, W2 are index having no dimension. Other variables are in hundreds of million RMB.

\section{Analytical Results}

\section{A The Competition Level of China's Banking System and its Evolution}

To date, there have been two stages of reform in Chinese banking system, from 1979 to 1992, and from 1993 to present. Stage one began with the creation of a "two tier" banking system, consisting of the People's Bank of China (the central bank), and four state owned banks: the Bank of China (BOC), the Agricultural Bank of China (ABC), the China Construction Bank (CCB) and the Industrial and Commercial Bank of China (ICBC). Initially there was a high degree of functional segmentation between them. By 1985, they were allowed to accept deposits and make loans to households and corporate (mainly SOEs), via nation-wide branches. By 1986, most had expanded to universal banks, with trust, securities, and insurance affiliates.

Table 2: The Level of Competition (The Value of H) of Banking System in China, 1996-2009

\begin{tabular}{c|ccccccc}
\hline & 1996 & 1997 & 1998 & 1999 & 2000 & 2001 & 2002 \\
\hline P1 & 0.051 & 0.001 & -0.113 & 0.121 & 0.003 & 0.137 & 0.49 \\
P2 & $0.438^{*}$ & $0.483 \$$ & $0.412 \$$ & $0.503^{*}$ & $0.413^{*}$ & $0.431^{*}$ & 0.403 \\
P3 & $0.274 \$$ & $0.201 \$$ & 0.132 & $0.034 \$$ & $0.153^{*}$ & $0.045 \$$ & $0.051^{*}$ \\
H & 0.763 & 0.685 & 0.431 & 0.658 & 0.569 & 0.631 & 0.944 \\
\hline
\end{tabular}




\begin{tabular}{c|ccccccc}
\hline & 2003 & 2004 & 2005 & 2006 & 2007 & 2008 & 2009 \\
\hline P1 & 0.022 & 0.159 & 0.158 & 0.167 & 0.221 & 0.431 & 0.555 \\
P2 & $0.598^{*}$ & $0.934 \$$ & $0.799 \$$ & 0.801 & $0.798^{*}$ & $0.997 \$$ & $0.871 \$$ \\
P3 & $0.011^{*}$ & $0.137^{*}$ & $0.201 \$$ & $0.211^{*}$ & $0.300^{*}$ & 0.243 & 0.355 \\
H & 0.632 & 1.23 & 1.158 & 1.179 & 1.319 & 1.311 & 1.532 \\
\hline
\end{tabular}

Note: $\$$ and $*$ indicates the results are significant at $1 \%$ and $5 \%$ level of confidence.

Between 1985 and 1992, to promote more competition, the Chinese government permitted the establishment of new "small and medium sized" commercial banks, which initially offered banking services to households and firms, mainly in the regions and cities.

In 1993, the State Council announced a second stage of bank reforms in the "Decision on Financial System Reform". One objective was to create a competitive commercial banking sector where state banks co-existed alongside other forms of banking institutions.

From table 2, we can find that although the level of competition in China's banking system varies greatly from 1996 to 2009, but generally speaking, the competition level increases over time.

\section{$B$ The relationship between market competition, law enforcement and banking system's efficiency in China}

In order to capture the relationship between the competition level of China's banking system and its efficiency, we make a regression here: let the efficiency of China's banking system act as dependent variable, and take the competition level of banking system and other macroeconomic variable as independent variable. An important issue we are going to explore here is the role of environmental factors in the relationship between competition and banking system's efficiency. As the literature indicates, the effect of market competition on institutes' efficiency to some extent depends on some environmental factors. And among them, the efficiency of law enforcement is an important one. Intuitively, if the law enforcement is more efficient, the disputes or arguments between companies will be much easier to settle. As a result, market competition will lead to greater efficiency. In this paper, the variable-LAW will proxy for the efficiency of law enforcement, which is the ratio of closed cases against total cases received by the regional courts.

In this way, we can partially verify the hypothesis in the introduction. If the parameter of competition level is positive, then it proves the "quiet life" hypothesis, i.e. the competition reduces the sloth of managers and enhances the efficiency of banking system. However, if the parameter is negative, then it shows that over competition in banking system hampers the bank-customer relationship and acts against the economic growth. From the beginning, we hypothesize that the efficiency of law enforcement could enhance the banking system's efficiency. So a positive coefficient of LAW is expected. The results of regression are as follows:
Table 3: The Relationship between Market Competition, Law Enforcement and the Banking System's Efficiency in China

\begin{tabular}{l|cc}
\hline & \multicolumn{2}{|c}{$\begin{array}{c}\text { Dependent variable: Efficiency of banking } \\
\text { system }\end{array}$} \\
\hline GDP growth & Coefficient & T-statistics \\
Inflation & 3.22 & 1.48 \\
LAW & 0.67 & 1.02 \\
Competition level of banking & $1.67^{* *}$ & 3.11 \\
system & $4.45^{* *}$ & 3.89 \\
Total assets of banking system & $0.22^{*}$ & 1.98 \\
R-Square & 0.65 & \\
\hline Note: ** and * indicates the results are significant at 1\% and 5\% level of \\
confidence.
\end{tabular}

As a result, the regression above shows that the "quiet life" hypothesis is supported in China's banking system. And the efficiency of law enforcement does indeed enhance the banking system's efficiency in China.

\section{Conclusion and Extensions}

In this paper, we empirically demonstrate the relationship between the market competition, law enforcement and the banking system's efficiency in China. We find that the "quiet life" hypothesis maybe valid in China's financial market. Besides, in regions where the law enforcement is more efficient, the effect of market competition on banking system's efficiency is much more salient. Of course, this study is preliminary, and could be extended further. For example, we could use other methods to calculate the competition level and efficiency, and different results may emerge. Besides, we could study the causality between the competition and efficiency in banking system in the future, which should be very interesting indeed.

Note:

This paper is an updated version of our working paper: The Relationship between Chinese Bank System's Competition and its Efficiency.

\section{REFERENCES}

[1] Aharony, Joseph, Chi-wen Lee, and T.J. Wong, (2000). Financial Packaging of IPO Firms in China, Journal of Accounting Research.

[2] Altunbas, Y., Gardener, E., and Moore, B. (2001). Efficiency in European Banking. European Economic Review, 45, 1931-1955.

[3] Bai, Chong-En, David Li, Yingyi Qian, and Yijiang Wang, (1999). Limiting government predation through anonymous banking: A theory with evidence from China, working paper, University of Maryland.

[4] Berger, G. N. (1993). The efficiency of financial institutions: a review and preview of research past, present and future. Journal of Banking and Finance, 17, 221-249.

[5] Bruton, Garry, and David Ahlstrom, (2002). An Industrial View of China's Venture Capital Industry: Explaining the Difference between China and the West, Journal of Business Venturing, Vol. 17, 1-27.

[6] Burkart, Mike, Fausto Panunzi, and Andrei Shleifer, (2002). Family Firms, NBER working paper 8776.

[7] Caselli, F., Esquivel, G. and Lefort, F. (1996). Reopening the convergence debate: A new look at cross-country growth empirics. Journal of Economic Growth, 1, 363-89. 
[8] Che, Jiahua, and Yingyi Qian, (1998a). Insecure property rights and government ownership of firms, Quarterly Journal of Economics, Vol. 113 (2), pp. 467-496.

[9] Chi guotai, Sun xiufeng and Lu dan(2005). The empirical investigation into the cost efficiency of commercial banks in China. The Economic Research Journal, issue 6.

[10] Claessens, Stijn, Simeon Djankov, and Larry Lang, (2000). The Separation of Ownership and Control in East Asian Corporations, Journal of Financial Economics, 58, 81-112.

[11] Demirguc-Kunt, Asli, and Vojislav Maksimovic, (1998). Law, finance, and firm growth, Journal of Finance, vol. 53 (6), 2107-37.

[12] Diamond, D. (1984). Financial intermediation as delegated monitoring. Review of Economic Studies, 51, 647-63.

[13] Ferri, G. and Mattesini, F. (1997). Finance, human capital and infrastructure: an empirical investigation of post-war Italian growth. Banca d'Italia, Temi di Discussione, 321.

[14] Fleisher, Belton, and Dongwei Su, (1997). An Empirical Investigation of Underpricing in Chinese IPOs, working paper, Ohio State University.

[15] Goldsmith, R. (1969). Financial Structure and Development. New Haven.

[16] Gomes, Armando, (2000). Going public without governance: managerial reputation effects, Journal of Finance, vol. 55, 615-646.

[17] Greif, Avner, (1989). Reputation and Coalitions in Medieval Trade: Evidence on the Maghribi Traders, Journal of Economic History, Vol. 49, 857-882.

[18] Islam, N. (1995). Growth empirics: A panel data approach. Quarterly Journal of Economics, 110, 4, 1127-70.

[19] Jin, Hehui, and Yingyi Qian, (1998). Public vs. private ownership of firms: evidence from rural China, Quarterly Journal of Economics, Vol. 113 (3), pp. 773-808.

[20] Jondrow, J., Lovell, C., and Schmidt, P. (1982). On the esti-mation of technical inefficiency in the stochastic frontier production function model. Journal of Econometrics, 19, 233-38.

[21] Kalirajan, K. and Shand, R. (1999). Frontier production functions and technical efficiency measures. Journal of Eco-nomic Surveys, 13, 14972.

[22] King, R. and Levine, R. (1993a). Finance and growth: Schumpeter might be right. Quarterly Journal of Economics, 108, 717-38.

[23] King, R. and Levine, R. (1993b). Finance, entrepreneurship, and growth: theory and evidence. Journal of Monetary Economics, 32, 513-42.

[24] King, Robert, and Ross Levine, (1993). Finance and Growth: Schumpeter Might Be Right, Quarterly Journal of Economics, Vol. 108 (3), 717-738.
[25] La Porta, Rafael, Florencio Lopez-de-Silanes, Andrei Shleifer, and Robert Vishny, (1997). Legal determinants of external finance, Journal of Finance, vol. 52, 1131-1150.

[26] Lau, Lawrence, Yingyi Qian, and Gerard Roland, (2000). Reform without Losers: An Interpretation of China's Dual-Track Approach to Transition, Journal of Political Economy, Vol. 108 (1), pp.120-143.

[27] Levin, A., Lin, C.F., (1993). Unit root tests in panel data: asymptotic and finite sample properties. Mimeo (September).

[28] Levine, R. (1997). Financial development and economic growth: Views and agenda. Journal of Economic Literature, 35, 688-726.

[29] Levine, Ross, (1999). Law, finance, and economic growth, Journal of Financial Intermediation, vol. 8 (1-2), 36-67.

[30] Li, David, (1996). A Theory of Ambiguous Property Rights in Transition Economies: The Case of the Chinese Non-state Sector, Journal of Comparative Economics, Vol. 23, 1-19.

[31] Mankiw, N., Romer, D. and Weil, D. (1992). A contribution to the empirics of economic growth. Quarterly Journal of Economic, 107, 2, 407-37.

[32] Orts, Eric, (2001). The Rule of Law in China, Vanderbilt Journal of Transitional Law, Vol. 34 (1), 43-115.

[33] Rajan, R. and Zingales, L. (1998). Financial dependence and growth. The American Economic Review, 88, 559-86.

[34] Rao Huacun.(2001). Financial liberalization, financial con-straint and interest rate marketizing. Northern economy and trade, issue 11.

[35] Riccardo Lucchetti and Luca Papi. (2001). Banks' inefficiency and economic growth: a micro-macro approach. Scottish Journal of Political Economy, 48, 400-424.

[36] Schipani, Cindy, and Junhai Liu, (2002). Corporate Governance in China: Then and Now, Columbia Business Law Review, Vol. 2002, 169.

[37] Schumpeter, J. A. (1934). Theorie der wirtschaftlichen Entwicklung. Duncker \& Humblot, Leipzig, 4th ed.

[38] Shirai, Sayuri, (2002), Is the Equity market Really Developed in the People's Republic of China? working paper, Keio University.

[39] Stiglitz, J. E. and Weiss, A. (1988). Banks as social ac-countants and screening device for the allocation of credit. NBER working paper, 2710

[40] Tan Ruyong.(1999). The empirical analysis of the relationship between Chinese financial development and economic growth. The Economic Research Journal, issue 10.

[41] Tadesse, Solomon, (2001). Financial Architecture and Economic Performance: International Evidence, working paper, University of South Carolina.

[42] Wang Guosong.(2001). Chinese interest rate control and interest rate marketizing. The Economic Research Journal, issue 6. 